\title{
Entrevista com Maria Immacolata Vassallo de Lopes
}

Clara Fernandes Meirelles

Clara Fernandes Meirelles | clara_meirelles@yahoo.com.br Mestre em Comunicação pela Universidade Federal do Rio de Janeiro - UFRJ.
Diversos motivos poderiam justificar uma entrevista com Maria Immacolata Vassallo de Lopes, professora titular da Escola de Comunicação e Artes da Universidade de São Paulo (ECA/USP), coordenadora do NP de Ficção Seriada da Intercom, entre outras tantas atividades relevantes. 0 foco principal, porém, do nosso encontro, em novembro de 2008 , foram as motivações e as dificuldades para a incorporação da telenovela como significativo objeto de estudo acadêmico em nosso país. 0 mote da conversa levou ainda a outros caminhos, como as especificidades da utilização de teóricos da Escola de Frankfurt e dos Estudos Culturais por pesquisadores brasileiros. As inovações trazidas pelo OBITEL (Observatório Ibero-Americano de Ficção Televisiva) também foram abordadas, bem como as novas perspectivas para as investigações sobre a ficção seriada.

0 que o leitor encontrará, abaixo, constitui uma versão resumida da entrevista que integrará a minha dissertação de mestrado (desenvolvida na Escola de Comunicação da UFRJ, sob a orientação do professor João Freire Filho), 
em que analiso as distintas revisões teóricas que permitiram a reabilitação da matriz melodramática nos contextos acadêmicos angloamericano e latino-americano.

\section{Clara Fernandes Meirelles: 0 cerne da} sua dissertação de mestrado é o consumo da programação radiofônica popular. No doutorado, o foco analítico se deslocou em direção à metodologia de pesquisa, uma temática que parece mobilizá-la até hoje. Como você avalia, retrospectivamente, a sua trajetória intelectual?

\section{Maria Immacolata Vassallo de Lopes: Fiz} graduação em Ciências Sociais, e sempre me interessou, durante o curso, a questão da comunicação de massa. Resolvi fazer um mestrado em comunicação, mas não sobre a questão da comunicação de massa em geral, e sim sobre os programas populares. Por causa de toda a minha formação crítica, eu queria trabalhar a questão das classes. Por isso, o meu mestrado foi sobre rádio dos pobres, selecionando alguns programas populares de rádio. Era uma pesquisa de recepção. Agora, esse trabalho será publicado em uma coletânea que está saindo sobre estudos de rádio, em que Maria Isabel Orofino mostra que naquele meu estudo já havia o popular e uma experiência metodológica. A única coisa que eu não fiz foi entrevistas com os emissores. Mas a emissão - os emissores - estavam lá. Analisei uma emissora de rádio, a questão dos conteúdos e a recepção, com ênfase nesta última. Havia também uma preocupação metodológica, porque, quando fui me tornando docente, as minhas áreas eram teoria e metodologia. A minha intenção inicial era estudar televisão, eu queria fazer trabalhos sobre o programa do Sílvio Santos. Eu devo a mudança à Ruth Cardoso. Numa discussão com ela sobre o projeto, ela disse que, antes de eu trabalhar com televisão, deveria trabalhar com o rádio, o veículo mais popular do Brasil e tão pouco explorado.

No doutorado, a minha intenção era fazer uma desconstrução de pesquisas sobre o popular, na área de Comunicação. Não é que eu tenha feito um trabalho sobre metodologia em geral. Eu queria fazer uma análise metodológica interna das pesquisas apresentadas em forma de teses e dissertações na área de Comunicação (eram teses e dissertações difíceis de ter para fazer essa análise). No entanto, como isso estava sendo muito complicado, vi que eu estava investindo muito mais no modelo de leitura dessas teses. Ou seja, a parte propriamente metodológica. Eu precisava de um instrumento, de procedimentos firmados de leitura desses códigos de teses de dissertação. Então, o meu doutorado acabou ficando com esse modelo, e depois o livro foi publicado. O que eu fazia era uma desconstrução de teses, que acabou dando origem a esse livro - que é de metodologia e também serve como modelo para a construção metodológica de uma pesquisa, seja de mestrado, seja de doutorado. O livro é exatamente a formulação de um modelo metodológico, embora primeiro ele tenha sido usado como modelo metodológico não de construção de pesquisa, mas de desconstrução de pesquisa; que eram as tais pesquisas sobre Comunicação Popular, com o intuito de entender o que havia de popular ali - tanto no sentido contemporâneo quanto no sentido 
de coisas que iam para festas religiosas, o que naquela época aparecia como popular.

Bom, com isso eu me fixei, em termos propriamente de trabalho, na chamada pesquisa de recepção. E trabalhando, portanto, em metodologia e em trabalhos de recepção. Eu de fato produzia ensaios sobre recepção. Mas o grande trabalho empírico e coletivo depois disso foi sobre a recepção da telenovela - ou seja, de assistência de televisão. Não importa o tipo de programa. Mas então, no caso, com a telenovela, eu voltei ao meu filão inicial, o popular. Eu organizei uma equipe em torno da proposta de fazer estudos de cultura - aí, no caso, havia todo o meu envolvimento com a linha de trabalho latino-americana, Jesús MartínBarbero, principalmente. Você sabe que Jesús Martín organizou, em 1985, um projeto latinoamericano de estudos de telenovela. Eu até uso esse projeto como texto metodológico, porque lá você tem um projeto de pesquisa, tanto da produção quanto do texto televisivo, da imagem e da recepção. Ele fez esse trabalho na Colômbia. Teresa Quiroz fez no Peru. No México, apesar dos problemas, ele deu origem aos trabalhos de Jorge González sobre a recepção de telenovela. E, no Brasil, quem trabalhou um pouco esse assunto - embora não tão amplamente, na questão da produção, do conteúdo e da recepção da telenovela - foi Renato Ortiz, autor de um trabalho de história e produção da telenovela, do qual a Sílvia Borelli também participou, junto com José Mario Ortiz Ramos. Embora fosse uma obra importante, eles não chegaram à recepção. O trabalho do Renato e de outros, no entanto, atendia à proposta latino-americana de estudos de telenovela.
Eu sempre pensei que os estudos de

Comunicação estavam avançando com contribuição nessas áreas. Mas, na pesquisa de recepção, sempre achei que a Comunicação havia ficado a dever em relação às pesquisas de recepção de telenovela. Esse foi o argumento para organizar esse grupo interdisciplinar $e$ fazer o trabalho do Vivendo com a telenovela. Esse grupo enfrentou a proposta de, a partir das mediações e da recepção, trabalhar com a questão propriamente da narrativa e até com a questão que nós chamamos de videotécnica, que também está lá e que depois deu vários outros doutorados desse grupo de pesquisa. São trabalhos de que eu gostei muitíssimo, em que havia uma proposta de exploração metodológica bastante ampla, que dava conta de uma pesquisa empírica de recepção de telenovela, mas que pretendia, a partir da recepção, ir para o plano da narrativa e também para ofato dessa narrativa ser de televisão.

\section{Então a motivação para a elaboração do} Vivendo com a Telenovela foi a defasagem que existia no Brasil em relação aos estudos de recepção de ficção seriada, especificamente?

Sim, de telenovela. Porque sobre televisão já havia uma bibliografia, de recepção de outros gêneros - de programas de auditório, de programas de mulheres, dos programas de auditório femininos -, mas a defasagem era particularmente de telenovela. 0 meu interesse era desde o inicio por essa narrativa popular é a influência de Gramsci na minha formação - e que batia naquele momento com os estudos latino-americanos das mediações propostos pelo Jesús Martín-Barbero. Mas ele tem uma 
proposta de um grande trabalho latinoamericano sobre a telenovela. É claro que Dos meios às mediações é de 1987, e essa proposta é de 1985 - ou seja, ele estava trabalhando ainda nessa questão, quando a fez, mas queria dizer efetivamente que era necessário fazer estudos de recepção, daquela questão da cultura por meio do cotidiano, como essa narrativa se inseria na vida das pessoas.

\section{Como avalia a adoção dos princípios teóricos propostos por Jesús Martín-Barbero, do estudo das mediações cotidianas? Houve um entusiasmo exagerado dos intelectuais na consideração da atividade do receptor?}

Nunca fui partidária dessa abordagem. Tanto no sentido de dar todo o poder ao receptor quanto daqueles primeiros estudos, chamados funcionalistas, da escola norte-americana, de dar todo o poder ao emissor, fazendo tábula rasa do receptor. Devido à minha formação - e é aí que a coisa deve ter uma certa diferenciação -, até hoje em dia eu acho que essas visões se devem ao precário trabalho de formação na área da Comunicação, tanto do ponto de vista teórico quanto metodológico. Não é que eu esteja propondo que a graduação em Comunicação seja um curso de Ciências Sociais, que eu acho que dá uma ótima base para pesquisa, com os procedimentos, as técnicas etc. Pelo menos o curso de Ciências Sociais que eu fiz [risos], que tinha trabalho com os autores, os clássicos, e até os contemporâneos. Até hoje, nós nos perguntamos: "Qual o lugar da teoria da Comunicação?" Não me refiro ao caso de pessoas de outras áreas, como a Ondina Fachel Leal, que é de antropologia, pois o objeto de comunicação delas não é para o resto da vida. São pessoas que não se detêm nesse objeto. Tanto que antes disso, eu ia falar sobre alguns estudos de recepção que me marcaram e que são da psicologia social, como o trabalho clássico da Ecléa Bosi, o Cultura de massa e cultura popular, que traz a leitura de operárias; e a da própria Ondina, Leitura social da novela das 8. Sobre rádio há um livro, pouco conhecido, Por trás das ondas da Rádio Nacional, de Miriam Goldfeder, uma dissertação de mestrado em Ciência Política da Unicamp. Ela é uma das primeiras que li a respeito da crítica que poderia haver no âmbito da recepção de uma maneira que não esquece de levar em conta a toda a estrutura social que a conforma. Mas ela não estava sendo, dessa maneira, frankfurtiana. Ela usa Gramsci de uma maneira brilhante para mostrar que o receptor é ativo. Ela vê uma interação entre o público e a eleição de determinados programas que lhe diziam respeito, nos quais se reconhecia. Ou seja, mais que um estudo de recepção, é um estudo das condições em que se dava o reconhecimento das classes populares nos programas da Rádio Nacional do Rio de Janeiro. Eu acho excelente, inclusive em termos metodológicos, uma pesquisa muito rigorosa e que não é o que chamamos de estudos dos efeitos em Comunicação. Há, ainda, é claro, o livro A noite da madrinha, que trabalha com a televisão, com programas de auditório. Mas, também, o Sérgio Miceli foi um estudioso que passou por essa questão do público de programa populares e depois não continuou.

Eu acho que em todos esses trabalhos a que me referi, a questão da comunicação de massa é uma coisa em que os pesquisadores de outras áreas do conhecimento queriam mexer e dizer 
alguma coisa a respeito. Eles deixaram muitas contribuições, mas acho que fomos nós, da Comunicação, que desenvolvemos essa questão e seguimos um caminho próprio.

É preciso reconhecer, então, que houve uma contribuição de outras áreas - notadamente da Antropologia - para a legitimação da telenovela na academia brasileira?

Sem dúvida. E da Sociologia, com toda a temática da estrutura. Faça uma releitura, hoje, de A noite da madrinha, que inclusive foi reeditado recentemente, com novo prefácio do autor. Porque até hoje o Sérgio Miceli não entende o trabalho dele ter feito tanto sucesso na área da Comunicação [risos], porque teve muita dificuldade para defendê-lo nas Ciências Sociais da USP, por ser um objeto não-legítimo, não era da Sociologia - movimentos operários, cidades... Mas eu acredito que essas pessoas deram uma contribuição que foi falar de um objeto que é nosso, da Comunicação. Por isso que eu falava da graduação em Comunicação, que na minha opinião forma para o mercado e descuida da formação mais teórica e metodológica. Porque não se trata de saber fazer pesquisa para ir para a pósgraduação. São disciplinas de formação. E para mim, passar por isso, fazer aquela discussão das teorias do nosso campo, das pesquisas existentes isso faz parte da formação, de uma boa formação do comunicador. Se ele vai para o mercado depois ou vai continuar na pesquisa, é outra questão.

Como a institucionalização de núcleos de pesquisa focados na telenovela contribuiu para a legitimação desse objeto?

Havia, evidentemente, um núcleo aqui na ECA (Escola de Comunicações e Artes - USP), que é de 1992. Foi criado aqui na Escola, então para mim a proximidade foi um fator importante, os colegas que a gente fez. Aliás, esse trabalho, Vivendo com a telenovela, era um subprojeto para um projeto maior que fazia parte do Núcleo de Pesquisa de Telenovela - hoje Centro de Estudos de Telenovela - quando a coordenação era da Maria Aparecida Baccega. Como estava trabalhando a questão da recepção, entrei nesse projeto. Mas foi um "projeto guarda-chuva", em que havia essa questão da telenovela, mas também outras: o estudo da recepção, a questão da teledramaturgia...

Bom, sobre isso eu gostaria de dizer duas coisas: primeiro, quero falar do programa de pósgraduação da ECA, onde estava o Núcleo e onde, portanto, uma linha de pesquisa no programa batia com a presença do grupo de pesquisa de telenovela. E a Intercom (Sociedade Brasileira de Estudos Interdisciplinares em Comunicação), que nasceu e ficou até pouco tempo com sede aqui na ECA, com o grupo de trabalho (GT) [de Ficção Seriada], que depois virou núcleo de pesquisa (NP). Então, quem faz um mestrado ou doutorado em telenovela volta para o seu lugar de origem, e você vai ver que começa a nuclear outras pessoas interessadas nisso.

Eu gostaria de lembrar, também, os TCCs (trabalhos de conclusão de curso). Há muitos TCCs sobre telenovela. Como a pessoa às vezes não continua, não dá para saber se ela fez um mestrado sobre o tema. Mas é um dos assuntos com bastante demanda, pelos pedidos que nós temos. Isso significa que a telenovela é um objeto que foi se fixando e ganhando legitimação. É claro que a Intercom, por meio do NP, teve um papel extraordinário nisso. 
Outra coisa que gostaria também de comentar é a questão de legitimidade, que não é apenas acadêmica, mas também uma legitimidade social. Até hoje, quando você fala que estuda telenovela, as pessoas estranham que telenovela possa ser estudada na universidade. Mas já não causa tanto impacto.

Queria dizer também como as emissoras produtoras de telenovela fazem parte também da legitimação desse tema, a interação que passou a ter. Gostaria de ressaltar, finalmente, a colaboração que foi sendo construída com a Globo, o SBT, o Ibope, etc. Ou seja, a presença desses estudos, que foram também ganhando legitimidade à medida que os próprios produtores reconhecem sua importância e valor. Isso mostra que eles não estão de costas para aquilo que se faz na academia.

\section{Então, os estudos sobre telenovela foram} validados primeiro na academia e posteriormente se alcançou o reconhecimento social e uma troca com os produtores de ficção seriada.

Não com os produtores, que é o que eu quis deixar personificado no projeto do Obitel. Quer dizer, o diálogo com a Globo foi um processo que durou muitos anos, porque, veja, ainda existem aqueles trabalhos reducionistas que só vêem na telenovela alienação, e que assim a coisa está dirigida - ainda tem, não é? A manipulação... Essas são noções muito ideológicas.

Evidentemente, há os condicionamentos, às vezes até em caráter de determinação, mas não se pode generalizar apenas com base neles. Eles são um dos aspectos que fazem parte desse nosso tema. Acredito que a pessoa possa até fazer um trabalho reforçando a problemática da audiência - não da recepção, mas da audiência -, mas ela tem que saber o que ela está fazendo, e deve principalmente ser muito contemporânea a isso. Eu acho que quando a gente fala da teoria da Escola de Frankfurt, nós, em Comunicação, não sabemos nem o quêe é isso, realmente. A Escola de Frankfurt não é somente indústria cultural e seus trabalhos. Sua obra é mais que isso. O que eu quero dizer é que nós precisamos saber de que maneira o pesquisador da Comunicação se apropria dos trabalhos da Escola de Frankfurt, da teoria crítica, e o seu uso. E aí também há duas questões: uma, na apropriação, que já é não saber, desconhecer o resto, quando se fala de Adorno e Horkheimer, até mesmo Benjamin. Hoje em dia, ninguém chega ao Krakauer ou ao Brecht, e outros. $E$ depois o uso que nós acabamos fazendo da teoria da indústria cultural nas pesquisas, mais reducionista ainda, que é aquela coisa de manipulação etc. Deve-se tomar cuidado, pois o que essa teoria revela não são reflexões que possam ir para o lixo. É preciso saber como formulavam, por exemplo, a questão das grandes corporações, a questão da mercadoria, da mercantilização da cultura. E a facilidade com que a Escola de Frankfurt é posta em oposição aos estudos culturais, eu acho uma aberração. Por isso que eu estava fazendo aquela crítica acerca de como nós Ipesquisadores de Comunicação] manuseamos e trabalhamos as teorias. Passou a onda da análise do discurso e agora temos a dos estudos culturais. Eu não vejo assim. Dizer que os estudos culturais não levam em conta a estrutura, não vêem as contradições da sociedade contemporânea, diversificada, de classes, eu também não concordo com isso. $O$ espírito do tempo... [risos] 
Dei um exemplo de reducionismo nos estudos via frankfurtianos. Porém, você poderia dizer a mesma coisa dos estudos de discurso da telenovela. Você não precisa ler os resultados. Você já sabe de antemão para onde esses estudos apontam. Ou seja: é um trabalho teórico malfeito. Há problemas tremendos na construção das pesquisas, nesse sentido.

\section{E como você avalia a leitura dos produtores e autores de ficção seriada em relação ao material produzido pela academia?}

Esse é um ponto muito importante. Nós esperamos que eles nos leiam e que nós os leiamos. Muita gente têm preconceito contra a telenovela porque nunca estudou. Fala-se chavões sobre a telenovela dentro do próprio campo acadêmico - ou seja, deslegitimando-a. Em todos os campos, você tem o que é menos ou mais importante de se pesquisar. Porém, acho que nós estamos trabalhando para conseguir valorizar o estudo da telenovela. Eu acho que o estágio a que a gente deveria chegar é não apenas dialogar com a área da produção, mas ir além disso - mostrar que os estudos podem contribuir para o desenvolvimento desse gênero. Precisamos fazer com que as pesquisas sobre telenovelas sejam lidas para que elas possam levar a problematizar de alguma maneira a produção, para que possam ir entrando no próprio processo de produção, na composição teledramatúrgica mesmo.

\section{Essas experiências já existem em outros países?}

Eu acho que é uma coisa bastante nova. No caso do Obitel, eu não saberia dizer de todos os países, porque cada situação é diferente. Mas sem dúvida o Brasil é uma exceção, dentro do conjunto de países em questão, tendo em vista o volume de pesquisas que temos sobre telenovela, e também a quantidade de pesquisadores existentes, a ponto de nós podermos criar uma extensão do Obitel, o Obitel Brasil, para aprofundar os dados do monitoramento da teleficção no país. Não importa se o pesquisador está no Amazonas ou em Santa Maria. Hoje temos que usar as condições dadas pela tecnologia da Internet para formarmos um grupo de pesquisa e trabalharmos a distância, mas que deve ser também um aprendizado de trabalhar coletivamente. Antes o grupo de pesquisa era eu e um aluno meu, depois eu e vários alunos meus, até porque grupo de pesquisa existia de acordo com a disponibilidade de cada um. Agora, isso está em mudança. Um novo modo de produção da pesquisa, do trabalho coletivo está criando grupos de pesquisa consolidados, institucionalizados, cujos membros não sejam do mesmo lugar.

A logística de trabalho na pesquisa é essencial. Nesse sentido, eu devo pensar que faço parte desse grupo e preciso alimentá-lo. Não pode ser só a pessoa que criou a idéia a responsável. Em um grupo pequeno isso seria mais fácil, mas em um grupo maior não. É preciso avançar e aprender. Não existe uma fórmula prévia de modos de trabalho se não existirem hábitos, uma cultura anterior que nos permita isso. Mas eu acho que nós estamos avançando. As ações da COMPÓS junto aos programas de pós-graduação, por exemplo, ou da INTERCOM, vêm propondo idéias de trabalho em rede. Porém, é preciso mais do que propostas. É preciso fazer com que as propostas vinguem. 
Nós estamos descobrindo caminhos para isso.

Eu sou otimista. Eu venho de um tempo em que a novela era desprezada. Ela nem era objeto de pesquisa. Agora, nós estamos falando de como trabalhar colaborativamente nas pesquisas sobre ela. Nós andamos. Muito. O trabalho pioneiro de Ondina Fachel Leal é dos anos 1980. Se nós pensarmos, até que essa caminhada foi rápida.

Nos países anglófonos, especialmente nos EUA e na Inglaterra, a legitimação da telenovela é, em parte, atravessada pela questão do gênero - do feminismo -, enquanto, na América Latina, as noções de mediações e resistência foram chaves mais úteis para as pesquisas...

Você tem razão. Naquilo que a América Latina e o Brasil estavam se desenvolvendo, no caso dos estudos de audiovisual, da televisão, eram sobre o quê? Sobre recepção. Tanto que nós não temos aqui aqueles estudos clássicos, estudos culturais, sobre o romance, os impressos. A começar pelo próprio estudo seminal de Richard Hoggart: o foco era a apropriação diferencial que o público popular fazia do jornal, ou seja, de uma mídia impressa. E nós não tivemos isso aqui. Eu acredito que as contribuições brasileiras e latino-americanas foram contribuições teóricas e metodológicas na recepção dos produtos audiovisuais. A gente fala hoje de estudos de linguagem nas novelas, mas eles são, em muito dos casos, estudos sobre a adaptação de obras literárias. Mas isso não é bem a característica básica da telenovela, na verdade não é da telenovela ou da minissérie, não é da sua produção, mas da literatura.

Eu acho que é pouquíssimo, teríamos que ir para o estudo da economia política da telenovela. Há alguns estudos sobre a Globo, sobre o que é a Globo enquanto organização. Mas não propriamente sobre telenovela. Eu estou falando de uma economia da telenovela. Eu estou falando de ver a novela enquanto negócio, usando o conceito forte de mercadoria, quer dizer, quanto ela custa, como é que ela entra, quais os sistemas de produção, a formatação dela, o mercado, público, audiência, distribuição... Nesses assuntos, eu acho que a gente não tem entrado muito.

Entre nós, o estudo de gênero na telenovela nunca chegou a ser um filão de pesquisa. Porém, desde o início, os estudos de recepção chamaram atenção para o que a novela trazia para a figura feminina, apesar desta quase sempre ser tratada dentro do contexto de classe e de família. Entretanto, a figura da mulher dentro da telenovela foi se tornando central e, de certo modo, podemos dizer que a telenovela tem sido feminista, a seu modo.

Sim, isso foi importante para determinadas pesquisas. 0 que eu estou querendo dizer é que os pesquisadores brasileiros procuraram outros tipos de perspectiva também.

Sim, eu acho. Atéfora da área da comunicação. Porque alguns trabalhos, como o da Heloísa Buarque de Almeida [Telenovela, Consumo e Gênero] estão nesse diapasão: estudos de gênero.

É preciso pensar um pouco a respeito do movimento feminista no Brasil. Porque eu acho que ao falar de estudos culturais, feminismo, sexismo, é preciso ver de que realidade você está falando. Depois da questão da mulher, veio a questão do homossexual. Começa a chamar a atenção, inclusive da opinião 
pública. 0 tratamento não é mais exótico nem reducionista, mas uma abordagem muito mais complexificada, de vários ângulos, a ponto de jogá-la e ela cair na discussão pública. A grande importância da telenovela é que ela se tornou um fórum de discussão, uma pauta de temas raciais, sexuais e de gênero.

Uma abordagem maior que contemple também as mediações?

Ah, sim, eu acho que sim. Eu acho que tem a ver muito disso. Não digo que a mediação de classe seja determinante, mas as coisas no Brasil andaram muito mais pelas diferenças de classe do que propriamente pelas diferenças de gênero.

Acredito que as mediações devem ser trabalhadas mais aprofundadamente, pois se há algo nos estudos de recepção que comporta crítica éo fato de que quase sempre todas as mediações se equivalem. Elas se equivalem? É a minha pergunta. Porque é uma coisa que a gente deveria investir, até para dizer assim, que "não é essa mediação, é essa, é outra, é outra, é outra..."

Hoje, por exemplo, o seu orientador, João Freire, trabalha com uma mediação que é fundamental, que é geracional. O jovem está aí perpassando. Os usos da Internet, da educação, do consumo. É importante estudar o adolescente, claro que é. Mas de onde que vem essa importância? Eu acho que vem da questão social que a mídia vai tematizar. Por isso, as mediações sendo históricas, sociais, culturais, devem ser teórica e metodologicamente tratadas de maneira diversa. Mas acho que num país como o Brasil, qualquer questão social transborda, só não vê quem não quer. Simplesmente passa-se por cima disso e aí eu acho que a pesquisa desanda.
Mas, em relação aos estudos de telenovela, a senhora acha que isso foi consciente?

Olha, se eu estou falando que está faltando abordagem econômica, está faltando a social também.

\section{Como a senhora avalia o legado do Barbero, Canclini e dos estudos culturais para a pesquisa sobre telenovela?}

Sobre Barbero e Canclini, eu não acho que eles são representantes dos estudos culturais na América Latina. Eles não são. São chamados assim de maneira incorreta. Fazer estudos de cultura é uma coisa, fazer estudos culturais é outra coisa. Na América Latina, nós temos uma tradição fortíssima de estudos de cultura. Nesses estudos de cultura, todo o desenho da sociedade, todas as suas características estão presentes. Os estudos culturais estão na Antropologia, na Sociologia, na Literatura, na Historiografia. É como eu estava falando da Escola de Frankfurt. Ela é uma abordagem teórico-metodológica. Inclusive quem se volta sobre os estudos culturais iniciais, têm que pensar até que ponto eles estão realmente sendo feitos hoje. Há, por exemplo, os estudos da Ana Carolina Escoteguy. Segundo ela, os estudos culturais são um pouco como o marxismo, aonde ele foi, ele se adaptou. Ai surgiram núcleos de estudos na Austrália, na Inglaterra, mesmo quando saíram daquela coisa de Birmingham. Como os de Frankfurt: eles iniciaram, mas a teoria crítica depois foi espalhada pelo mundo, inclusive criticada pela própria matriz que eles estavam inseridos, que era o marxismo. Então é preciso estudar certos autores que falam 
dos marxismos, do marxismo oriental e do ocidental, para ver realmente qual é a concepção dessas coisas.

Senão fica muito redutor.

É que às vezes não se colocam na discussão propriedades que têm que ser colocadas. Porque não colocá-las é ignorá-las, é um desconhecimento. Não sei se eu diria redutor; é um uso, uma concepção que não corresponde.

Por isso, se alguém quer pesquisar sob o prisma dos estudos culturais, precisa mergulhar nisso. E não pegar o último autor. Ou ficar no pensamento de "eu vou pegar o livrinho do Stuart Hall que fala das identidades na pósmodernidade". Não é por aí.

\section{E houve aqui uma fundamentação teórica} completamente diferente para esses estudos.

Na Comunicação. Primeiro que esses dois autores, o Barbero e o Canclini, eles não são propriamente autores da Comunicação e isso não vale para eles. Eles trabalham muito mais sobre cultura do que sobre comunicação, ou tanto quanto. Uma vez, o Canclini falou: "Por que vocês falam tanto de mim nos congressos de Comunicação quando eu não sou de comunicação?". Claro que, tirando a piada, o que importa é que ele escreve e daí o público se apropria. É fato que ele é um autor útil para os estudos de Comunicação. Vai pelas referências que você vê. Analise as citações bibliográficas entre nós. Foucault e Baudrillard, como chamá-los, filósofos, sociolólogos? Como chamar o Edgar Morin? O sociólogo Edgar Morin? Não, eles são pensadores, são autores transdisciplinares.

\section{E essa transdiciplinaridade teria alimentado} os estudos de telenovelas na América Latina?

Sem dúvida. É daí que saem os trabalhos sobre linguagem, sobre o discurso. Nós trabalhamos com uma narrativa, um discurso ficcional da televisão. As coisas mais complicadas de trabalhar metodologicamente entram aí.

Uma última pergunta. Como a senhora vê a relação entre as inovações de formato ficcional que estão surgindo na televisão e a queda de audiência das telenovelas? Como as pesquisas acadêmicas estão refletindo esse processo?

Eu acho que a novela ainda é hegemônica enquanto formato. Na audiência de televisão, a novela continua aparecendo entre as maiores. A questão é que hoje não há mais como alcançar a faixa dos 60,70 pontos que era o que alcançava uma novela de sucesso. Depois, essa novela de sucesso passou para a faixa de 50 pontos e hoje o patamar está nos 40 pontos. Quando alguma cai para os 30, a mídia generaliza: "ah, acabou a novela!". Além das razões da queda poderem ser fortuitas (é preciso que se caracterize como tendência), é preciso ampliar o contexto. A gente tem que observar para onde a narrativa ficcional está migrando. As séries e minisséries que estão indo para o cabo, feitas por produtoras independentes e em sociedade com empresas estrangeiras, como a Sony e a HBO. Isso eu acho que é muito interessante para se acompanhar. Existe todo um knowhow, porque você sabe fazer série e minissérie na TV aberta, mas e na TV fechada? Eis aí um desafio interessante. 


\section{Expediente}

A revista E-Compós é a publicação científica em formato eletrônico da Associação Nacional dos Programas de Pós-Graduação em Comunicação (Compós). Lançada em 2004, tem como principal finalidade difundir a produção acadêmica de pesquisadores da área de Comunicação, inseridos em instituições do Brasil e do exterior.
E-COMPÓS I www.e-compos.org.br I E-ISSN 1808-2599

Revista da Associação Nacional dos Programas de Pós-Graduação em Comunicação. Brasília, v.11, n.2, maio/ago. 2008.

A identificação das edições, a partir de 2008 passa a ser volume anual com três números.

\section{CONSELHO EDITORIAL}

\section{Afonso Albuquerque}

Universidade Federal Fluminense, Brasil

Alberto Carlos Augusto Klein

Universidade Estadual de Londrina, Brasi

Alex Fernando Teixeira Primo

Universidade Federal do Rio Grande do Sul, Brasi

Alfredo Vizeu

Universidade Federal de Pernambuco, Brasil

Ana Carolina Damboriarena Escosteguy

Pontifícia Universidade Católica do Rio Grande do Sul, Brasil

Ana Silvia Lopes Davi Médola

Universidade Estadual Paulista, Brasil

André Luiz Martins Lemos

Universidade Federal da Bahia, Brasil

Ângela Freire Prysthon

Universidade Federal de Pernambuco, Brasi

Antônio Fausto Neto

Universidade do Vale do Rio dos Sinos, Brasil

Antonio Carlos Hohlfeldt

Pontifícia Universidade Católica do Rio Grande do Sul, Brasil

Arlindo Ribeiro Machado

Universidade de São Paulo, Brasil

César Geraldo Guimarães

Universidade Federal de Minas Gerais, Brasi

Cristiane Freitas Gutfreind

Pontifícia Universidade Católica do Rio Grande do Sul, Brasi

Denilson Lopes

Universidade Federal do Rio de Janeiro, Brasil

Eduardo Peñuela Cañizal

Universidade Paulista, Brasil

Erick Felinto de Oliveira

Universidade do Estado do Rio de Janeiro, Brasil

Francisco Menezes Martins

Universidade Tuiuti do Paraná, Brasil

Gelson Santana

Universidade Anhembi/Morumbi, Brasi

Hector Ospina

Universidad de Manizales, Colômbia

leda Tucherman

Universidade Federal do Rio de Janeiro, Brasil

Itania Maria Mota Gomes

Universidade Federal da Bahia, Brasil

Janice Caiafa

Universidade Federal do Rio de Janeiro, Brasil

Jeder Silveira Janotti Junior

Universidade Federal da Bahia, Brasil
John DH Downing

University of Texas at Austin, Estados Unidos

José Luiz Aidar Prado

Pontifícia Universidade Católica de São Paulo, Brasil

José Luiz Warren Jardim Gomes Braga

Universidade do Vale do Rio dos Sinos, Brasi

Juremir Machado da Silva

Pontifícia Universidade Católica do Rio Grande do Sul, Brasil

Lorraine Leu

University of Bristol, Grã-Bretanha

Luiz Claudio Martino

Universidade de Brasília, Brasil

Maria Immacolata Vassallo de Lopes

Universidade de São Paulo, Brasil

Maria Lucia Santaella

Pontifícia Universidade Católica de São Paulo, Brasil

Mauro Pereira Porto

Tulane University, Estados Unidos

Muniz Sodre de Araujo Cabral

Universidade Federal do Rio de Janeiro, Brasil

Nilda Aparecida Jacks

Universidade Federal do Rio Grande do Sul, Brasil

Paulo Roberto Gibaldi Vaz

Universidade Federal do Rio de Janeiro, Brasil

Renato Cordeiro Gomes

Pontifícia Universidade Católica do Rio de Janeiro, Brasil

Ronaldo George Helal

Universidade do Estado do Rio de Janeiro, Brasil

Rosana de Lima Soares

Universidade de São Paulo, Brasil

Rossana Reguillo

Instituto Tecnológico y de Estudios Superiores do Occidente, México

Rousiley Celi Moreira Maia

Universidade Federal de Minas Gerais, Brasil

Sebastião Carlos de Morais Squirra

Universidade Metodista de São Paulo, Brasil

Simone Maria Andrade Pereira de Sá

Universidade Federal Fluminense, Brasil

Suzete Venturelli

Universidade de Brasília, Brasil

Valério Cruz Brittos

Universidade do Vale do Rio dos Sinos, Brasil

Veneza Mayora Ronsini

Universidade Federal de Santa Maria, Brasil

Vera Regina Veiga França

Universidade Federal de Minas Gerais, Brasil
COMISSÃO EDITORIAL

Ana Gruszynski I Universidade Federal do Rio Grande do Sul, Brasil João Freire Filho I Universidade Federal do Rio de Janeiro, Brasil Rose Melo Rocha I Escola Superior de Propaganda e Marketing, Brasil

\section{CONSULTORES AD HOC}

Aníbal Bragança I Universidade Federal Fluminense, Brasil Gisela Castro I Escola Superior de Propaganda e Marketing, Brasil

Gislene Silva I Universidade Federal de Santa Catarina, Brasil

Maria Helena Weber I Universidade Federal do Rio Grande do Sul, Brasil

Rosana de Lima Soares I Universidade de São Paulo, Brasil

Tania Hoff I Escola Superior de Propaganda e Marketing, Brasil

REVISÃO DE TEXTO E TRADUÇÃo I Everton Cardoso

ASSISTÊNCIA EDITORIAL E EDITORAÇÃO ELETRÔNICA I Raquel Castedo
COMPÓS I www.compos.org.br

Associação Nacional dos Programas de Pós-Graduação em Comunicação

Presidente

Erick Felinto de Oliveira

Universidade do Estado do Rio de Janeiro, Brasil erickfelinto@uol.com.br

Vice-presidente

Ana Silvia Lopes Davi Médola

Universidade Estadual Paulista, Brasil

asilvia@faac.unesp.br

Secretária-Geral

Denize Correa Araújo

Universidade Tuiuti do Paraná, Brasil

denizearaujo@hotmail.com 